\title{
Determination and assessment of phosphorus assimilation capacity applying Vollenweider approach for Hazar Lake
}

\author{
Selma Ayaz*, Mehmet Dilaver \\ TUBITAK Marmara Research Center, Environment and Cleaner Production Institute, 41470, Kocaeli, Turkey, \\ selma.ayaz@tubitak.gov.tr, ORCID: 0000-0001-5932-9060,mehmet.dilaver@tubitak.gov.tr, ORCID: 0000-0002-9805-9064
}

\begin{abstract}
A B S T R A C T
Eutrophication is a natural process for natural lakes and dams and the hydraulic retention time of this process is directly related to whether the assimilation capacity is exceeded depending on the current water quality and pressures consists of point and diffuse sources. Exceeding assimilation capacity is accepted good for biological productivity however this situation cannot be desired for water resources any time and preventive actions need to be taken to sustain good water quality. The Vollenweider OECD Method is a widely used and accepted approach in order to calculate current phosphorus loads for phosphorus limiting lakes and dams. In addition to OECD method, rational method is used frequently in calculating the flowrates via surface runoff after precipitation. In this study, the calculation of the assimilation capacity for phosphorus limiting lakes and dams using the Vollenweider Method and rational method for calculation of flowrates were applied for Hazar Lake's Basin example. When the apply proposed approach Hazar Lake's TP loading might be increased 3.7 times a year for desired oligotrophic upper boundary condition and 13.7 times a year for mesotrophic state boundary condition.
\end{abstract}

\author{
ARTICLE INFO \\ Research article \\ Received: 02.03.2021 \\ Accepted: 24.03.2021 \\ Keywords: \\ Hazar Lake, \\ phosphorus assimilation \\ capacity, \\ Vollenweider method
}

${ }^{*}$ Corresponding author

\section{Introduction}

Eutrophication is a natural process that results from accumulation of nutrients in receiving waterbodies. This process is occurred availability of plenty of least one limiting nutrient that causes excessive algal growth especially in lakes, ponds and dams. Even eutrophication occurs naturally over many decades, human activities, land use and agricultural activities may speed up the processes with additional nutrient via point and diffuse sources input. Limiting factor is determined that nutrient in shortest supply relative to plant growth requirements. Plants will grow until stopped by this limitation; for example, phosphorus in summer, temperature or light in fall or winter.

Researchers mentioned that nutrient limitation may not detectable easily with analytical methods however measured concentrations may be used for determination of nutrient limiting factor and trophic states for surface waterbodies [13]. When the literature studies are examined, it is seen that phosphorus becomes prominent as the limiting nutrient in many lakes [1- 5]. Determining the limiting nutrient is important in respect of controlling pollution in lakes under eutrophication threat. The use of TN:TP ratio is a general approach to determine the limiting nutrient $[3,4]$. As specified in the literature, the fact that TN:TP ratio is over 17 indicates that phosphorus is the limiting nutrient in the lake, and that it is less than 10 indicates that nitrogen is the limiting nutrient in the lake [3]. The TP concentration values are also used for the TN:TP ratios remaining out of these limits specified in the literature. For the lakes where TN:TP ratio is between 10 and 17 , the fact that TP concentration is over $1 \mathrm{mg} / \mathrm{L}$ indicates that nitrogen is the limiting nutrient in the lake, and that it is less than $10 \mu \mathrm{g} / \mathrm{L}$ indicates that phosphorus is the limiting nutrient in the lake $[4,6]$.

Different approaches have been investigated in order to calculate the assimilation capacities of the lake and dam reservoirs considered within the scope of the study. Among the main approaches considered are [1, 7-10]. Among these approaches, when Vollenweider's (1976) method is compared with the others, it is considered to be a more advantageous method since it deals with depth and surface area criteria. For this reason, the Vollenweider method has been preferred in the calculation of the assimilation capacity over the phosphorus parameter. Using the Vollenweider method, the relationship between the nutrient loads and the primary production has been calculated. In the method, the TP load and the chlorophyll-a parameter, among the loads coming from the 
drainage basin of the lake water bodies, have been associated with each other.

Studied area Hazar Lake is a deep tectonic lake located in Eastern Anatolia [11]. Koçer and Şen (2014) was evaluate the nutrients ratio of Hazar Lake based on recent literature [1214] and concentrations of nutrients according to OECD [15], Whittaker [16] and Vollenweider and Kerekes [17], Lake Hazar was found mesotrophic state [18]. Another local study finding lake is a typical an oligotrophic alkaline lake [11]. Even, current trophic state is between oligotrophic and mesotrophic level lake surround is getting high attraction with human activities therefore; lake is needed to be protected as mesotrophic state least in order to protect national importance wetland statute [19].

In this study, the assimilation capacity for phosphorus was calculated based on the current long data of chlorophyll-a condition of the Hazar Lake using the Vollenweider approach.

\section{Materials and methods}

\subsection{Study area}

Hazar Lake Basin, located in the Elazığ Province in Turkey. Hazar Lake Basin is geographically located between $38.359523^{\circ}$ - $38.562718^{\circ}$ Latitudes and $39.134583^{\circ}$ $39.587919^{\circ}$ Longitudes according to ED50 Datum TM 39 Degree Projection System (Figure 1). The basin area is about 38374 hectare (ha). Study area consists of Hazar Lake, Zıkkım, Behrimaz, Kürk and Baharın rivers and the lake area is about 7897 ha based on CORINE 2018 data and at 1238 meter (m) elevation above the sea level. Behrimaz is the longest river is about $24.2 \mathrm{~km}$ length that connected to the Hazar Lake (Figure 2) and it contributes about $70 \%$ of total surface flow to the Hazar Lake [20].

The lake is tectonic formed and second deepest natural lake in Turkey. Various deepest depths were reported between $80 \mathrm{~m}$ to $300 \mathrm{~m}$ in the literature [21]. Hazar Lake is having a highly alkaline and hardness characteristics and a high dissolved solids content, which results from carbonate concentrations [18]. The Lake is also having national importance wetland protection statue so far and possible candidate of RAMSAR site.

Hazar Lake Basin settlements are mainly villages and total 29 settlements located (Figure 3) within the basin with the 7831 people [22]. Usual settlements are not making pressure to the lake but this area is getting high attention and open to expansion.

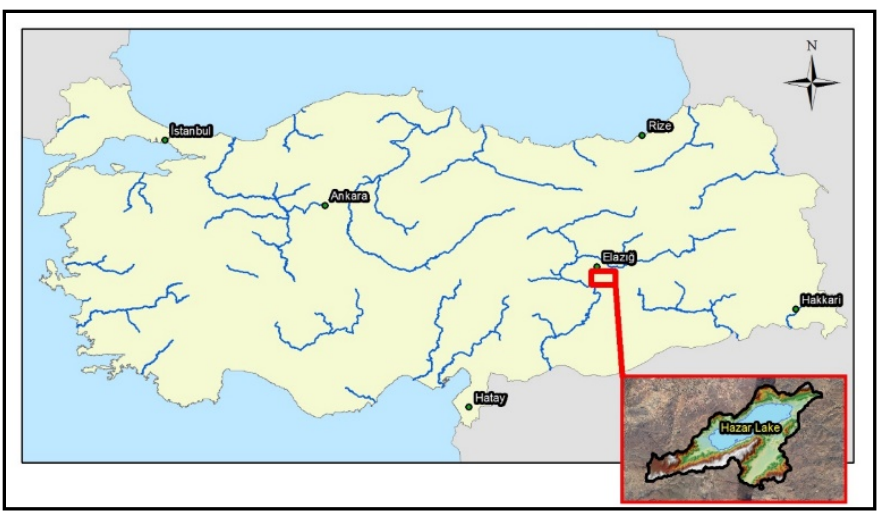

Figure 1. Hazar Lake

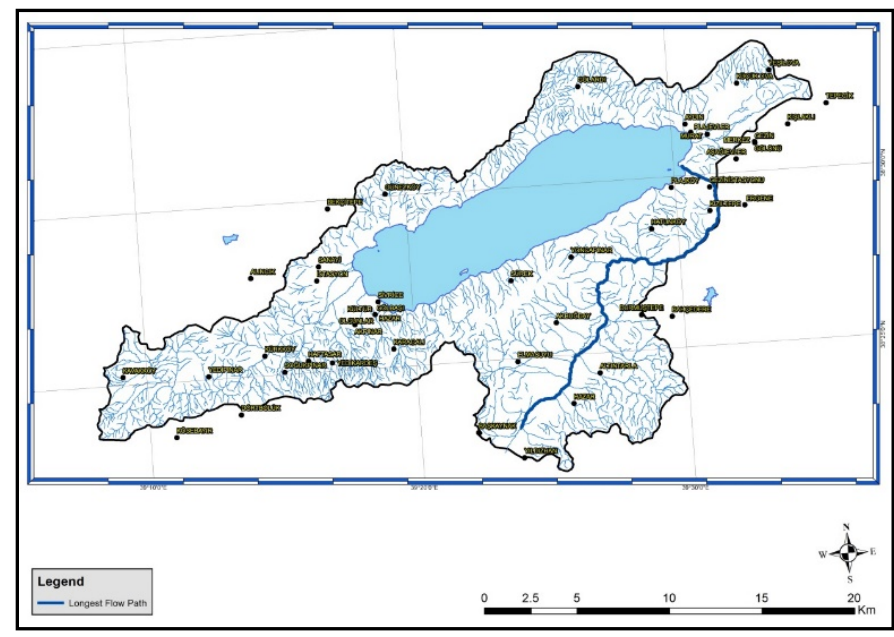

Figure 2. Hazar Lake’s Basin waterbodies

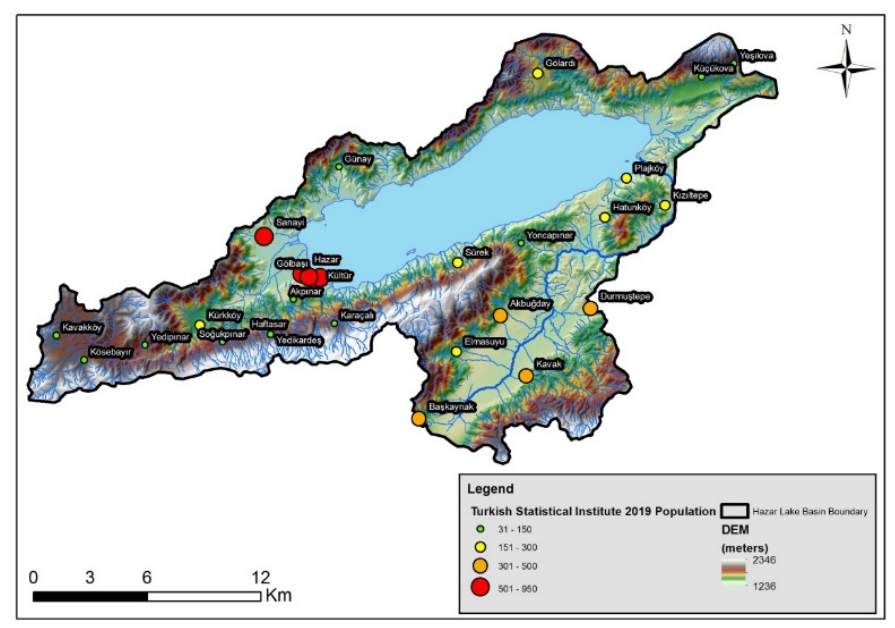

Figure 3. Hazar Lake's settlements and population

Detailed land use information was given in Figure 3. Forest and semi natural areas, agricultural areas and waterbodies areas are about $55.4 \%, 20.6 \%$ and $23.1 \%$ of total land use respectively based on CORINE 2018 data. According to this land use information that Hazar Lake's Basin is not high pressure in terms of land use (Figure 4). 
It was selected as the study area that getting intention and threatening urban activities. Hazar Lake is natural deep lake and current trophic state is oligotrophic but the lake is under threat due to civilization. Therefore, lake water quality must be maintained with urgent actions.

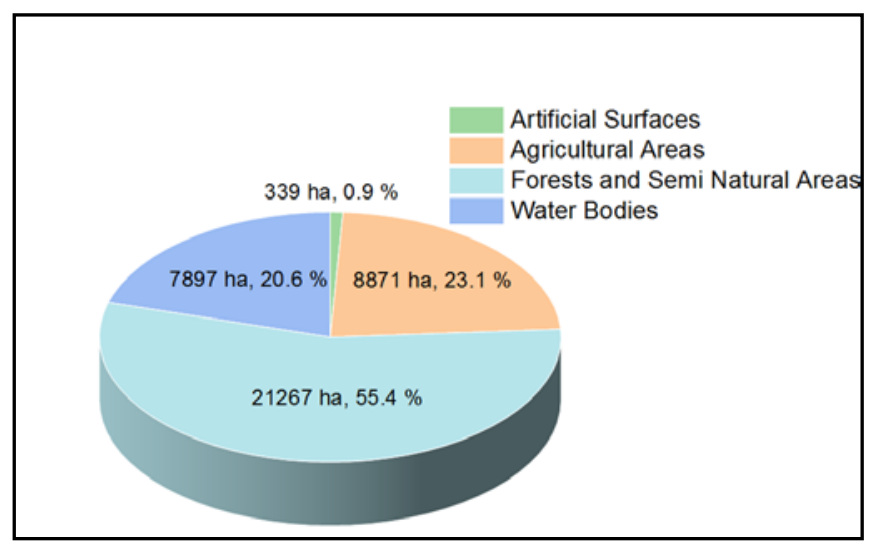

Figure 4. Hazar Lake's Basin land use distribution (CORINE 2018)

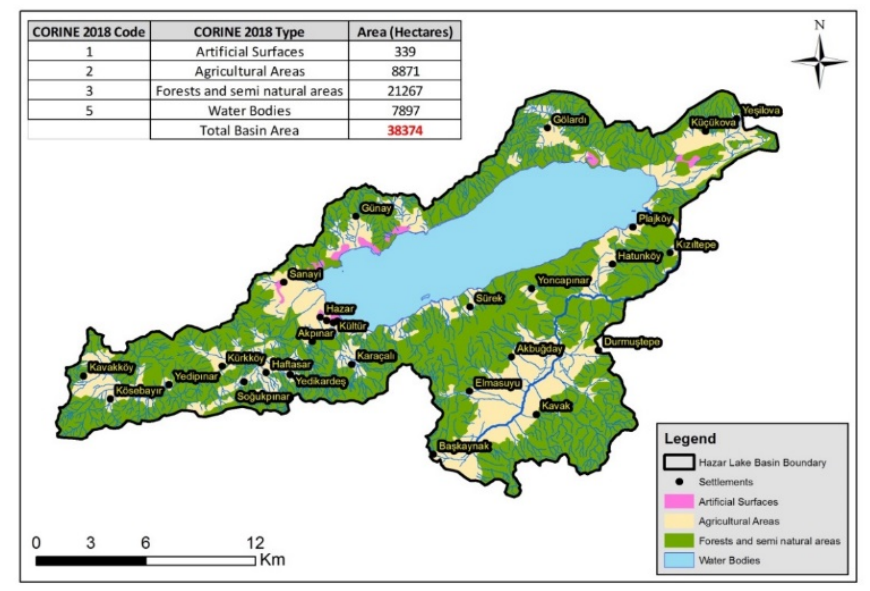

Figure 5. Hazar Lake Land Use map (CORINE 2018)

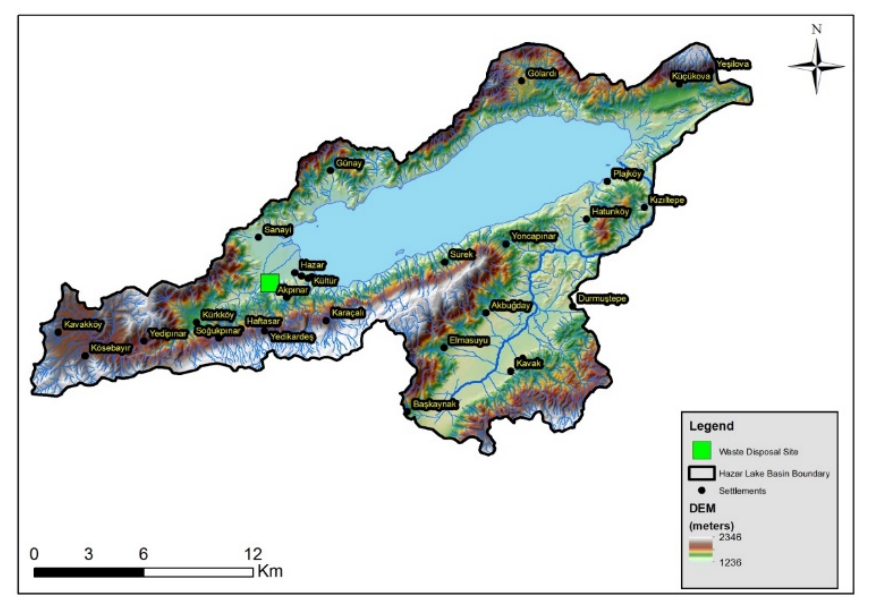

There is no any industrialization and municipal wastewater discharge through receiving water bodies. Only pressures are one solid waste disposal site where it is located downstream of the basin and limited agricultural activities.

\subsection{Peak surface run-off calculation with rational method}

The rational method is one of the oldest methods used in surface runoff calculations. Although it is criticized since it does not need very detailed academic data, it is still widely applied in engineering calculations today due to this quality. Since some water bodies whose assimilation capacity has to be determined within the scope of the study is not included in the drainage basins, the rational method was preferred as the calculation method in order to determine the hydraulic retention times. As explained in the previous section, the reason for this preference is the fact that the rational method is the appropriate method in respect usability of available data. It is important to know the limitations and assumptions arising from this method in the application of the rational method.

The assumptions in the application of the rational method; i) precipitation has uniformly dispersed over the entire drainage area and is constant over time, ii) the calculated peak discharge has the same recurrence period as the statistically used precipitation intensity (I), iii) the surface runoff coefficient (c) is constant during the whole precipitation. On the other hand; the warning that should not be ignored in the application are the smaller the drainage area, the more accurate the results are and the rational method points to only one peak point in the unit hydrograph.

Equation used in the rational method:

$$
Q=\operatorname{ciA} / 3600
$$

(Equation 1)

Q: Maximum surface runoff (peak discharge) $\left(\mathrm{m}^{3} / \mathrm{s}\right)$

C: surface runoff coefficient (land cover/coefficient according to use) i: Intensity of precipitation falling in the drainage time of water according to 10-year recurrence

A: Basin area (ha)

3600 number found out in the equation is the multiplier used during transition from the imperial units into the SI metric units.

The surface runoff coefficients decrease as the water leakiness increases according to land cover use. Its value is between 0 1 . While the coefficient for the soil surfaces with vegetation cover approaches to 0 , it approaches to 1 since the leak proof surfaces increases due to settlement and commercial activities. In the event there are mixed land use types within the basin, the surface runoff coefficients calculated according to the land use are calculated by the weighted average method. Since this is the case in all separate land uses within the basin, the weighted surface runoff coefficients have been determined according to the following formulation (Eq.2.).

Figure 6. Artificial Pressures 


$$
\mathrm{C}_{\mathrm{w}}=\frac{\sum_{\mathrm{i}=0}^{\mathrm{n}} C j A j}{\sum_{\mathrm{i}=0}^{\mathrm{n}} A j}
$$

$C_{W}=$ weighted surface runoff coefficient, $C_{j}=$ surface runoff coefficient for $\mathrm{j}$ area

$A_{j}=$ surface area $\left(\mathrm{m}^{2}\right), n=$ number of land use type

The simplified rational method used in this study has been presented in Table 1, the surface runoff coefficients (c) table.

Table 1. Surface runoff coefficients (c) depending on the land cover use

\begin{tabular}{lr}
\hline $\begin{array}{l}\text { Land Cover } \\
\text { Use }\end{array}$ & Surface Runoff Coefficient, c \\
\hline Grass (garden) & $0.05-0.35$ \\
Forest & $0.05-0.25$ \\
Cultivable area & $0.08-0.41$ \\
Grassland & $0.1-0.5$ \\
Parks, & $0.1-0.25$ \\
Undeveloped & $0.1-0.3$ \\
\hline Pasture land & $0.12-0.62$ \\
Settlement & $0.3-0.75$ \\
Commercial & $0.5-0.95$ \\
Industrial areas & $0.5-0.9$ \\
Asphalt roads & $0.7-0.95$ \\
Covering roads & $0.7-0.85$ \\
Roofs & $0.75-0.95$ \\
Concrete roads & $0.7-0.95$ \\
\hline
\end{tabular}

The water drainage time (Tc) is the time that passes until the precipitation falling to the top of the basin reaches at the output point, after the soil is saturated with precipitation and the small depressions in the area are filled with water. The basin varies according to the watercourse slope, vegetation cover status and other hydrological conditions.

$$
K=L / \sqrt{S} \quad \text { (Equation 3) }
$$

L: longest runoff length in the basin (m), S: slope along runoff (\%)

$$
T c=0.0195 x K^{0.77} \quad \text { (Equation 4) }
$$

The 10-year recurring 1-hour precipitation intensity $(\mathrm{mm} / \mathrm{h})$ values presented in Table 2 are the figures obtained from the lecture notes of Prof. Dr. Orhan Doğan, and use of the rational method in calculation of the precipitation intensity (I) has been found to be appropriate for the conditions in Turkey.

Table 2. 10 year recurring 1-hour precipitation intensity $(\mathrm{mm} / \mathrm{h})$

\begin{tabular}{lclclc}
\hline Station & $\begin{array}{c}\text { Precipit } \\
\text { ation } \\
\text { Intensit } \\
\mathbf{y}\end{array}$ & $\begin{array}{l}\text { Station } \\
\text { Name }\end{array}$ & $\begin{array}{c}\text { Precipit } \\
\text { ation } \\
\text { Intensity } \\
\text { (mm/h) }\end{array}$ & $\begin{array}{l}\text { Station } \\
\text { Name }\end{array}$ & $\begin{array}{c}\text { Precip } \\
\text { itation } \\
\text { Intens } \\
\text { ity }\end{array}$ \\
\hline İzmir & 33,5 & Kemalpaş & 29,7 & Manisa & 41,8 \\
Muğla & 56,7 & Aydın & 23,0 & Denizli & 32,0 \\
Mersin & 38,5 & Adana & 36,0 & Hatay & 65,0 \\
Dörtyol & 58,0 & Gaziantep & 30,0 & İslâhiye & 19,9 \\
Florya & 25,0 & Sarıyer & 34,0 & Çorlu & 50,0 \\
Edirne & 36,4 & Ankara & 30,0 & Bolu & 17,2 \\
Zonguldak & 68,0 & Niğde & 32,2 & Kastamonu & 40,0 \\
İnebolu & 46,0 & Çankırı & 25,0 & Çorum & 35,0 \\
Antalya & 60,0 & Isparta & 32,4 & Konya & 13,0 \\
Diyarbakır & 22,0 & Şanlıurfa & 28,6 & Ceylanpınar & 19,5 \\
Siirt & 23,0 & Kayseri & 23,0 & Kırşehir & 21,5 \\
Yozgat & 16,0 & Erzurum & 21,4 & Erzincan & 25,0 \\
Malatya & 22,5 & Elazı̆ & $\mathbf{2 8 , 5}$ & Samsun & 40,0 \\
Samsun & 40,0 & Merzifon & 25,4 & Van & 23,0 \\
Sivas & 21,5 & Trabzon & 36,0 & Rize & 70,0 \\
Eskişehir & 33,4 & Afyon & 30,3 & Kütahya & 29,5 \\
Uşak & 26,5 & Bilecik & 22,7 & Bursa & 28,5 \\
Balıkesir & 33,5 & Bandırma & 50,0 & Çanakkale & 52,0 \\
Kocaeli & 38,0 & & & & \\
\hline
\end{tabular}

The values, the length (L) of the main runoff and the slope (S) along the runoff, have been calculated by using GIS for Hazar Lake's Basin. Tc values have been calculated by placing these values in equations (3) and (4), respectively. For the meteorological station closest to the basin where the Tc value has been calculated, the value present in the table above has been selected. Later on, the correction coefficient has been applied according to Tc value (Table 3 ).

Table 3. Correction coefficients corresponding to Tc values

\begin{tabular}{cc}
\hline Duration (minute) & $\begin{array}{c}\text { Correction } \\
\text { Coefficient }\end{array}$ \\
\hline 5 & 0,29 \\
10 & 0,45 \\
15 & 0,57 \\
20 & 0,66 \\
30 & 0,79 \\
40 & 0,88 \\
50 & 0,95 \\
60 & 1,00 \\
\hline
\end{tabular}

The values seen in Table $\mathbf{2}$ are one-hour precipitation correction coefficients, and the values in Table $\mathbf{3}$ have been subjected to correction according to the calculated Tc values duration.

$$
\begin{aligned}
& \text { Corrected I value }(\mathrm{mm} / \mathrm{h}) \\
& \qquad=I \times 1.00 \times\left(\frac{I}{T c}\right)
\end{aligned}
$$

After the precipitation intensity (I) value is calculated in this way, the flow rate calculations have been completed by locating all the requirements of the equation (1) into their places. 


\subsection{Determining normalized total phosphorus with Vollenweider approach}

While Vollenweider developed this method, he carried out examinations on phosphorus load and the ecosystem's response to this for 5 years in Western Europe, North America, Japan and Australia, in a total of 22 countries, on about 200 different water bodies (Figure 7). As a result of this study, a statistical correlation has been developed, which normalizes the annual areal total phosphorus (TP) load (Lp) falling on surface a lake with average depth (Z) and hydraulic retention time $(\mathrm{Tw})[5]$.

$$
\begin{aligned}
& \text { Normalized TP load }(\mathrm{mg} / \mathrm{m} 3) \\
& =\frac{\mathrm{L}(\mathrm{P}) / \mathrm{qs}}{1+\sqrt{T w}}
\end{aligned}
$$

$\mathrm{L}(\mathrm{P})=$ Annual TP load on the area drained into the lake water body (mg P/m²/y)

$\mathrm{q}_{\mathrm{s}}=$ Value obtained by dividing depth (m) into hydraulic retention time (y)

$\mathrm{T}_{\mathrm{w}}=$ Hydraulic retention time $(\mathrm{y})$

These values have been placed in their places in Equation (6), and the value of normalized phosphorus load for each basin has been found.

Hydraulic retention times, one of the most important parameters that have to be known when this method is used, have been calculated by using the values of the Current Flowrate Observation Stations (CFOS) obtained from the General Directorate of State Hydraulic Works (DSI). If the CFOS output values of the dam reservoir and/or lake water bodies are in the water bodies that do not have output values, the annual runoff has been determined by using the total input AGI values, and the hydraulic retention times have been calculated by proportioning this amount to the volume of water body. The total current values required for calculation of the hydraulic retention time of the lake or dam reservoir water bodies without any AGI values have been calculated by applying the "Rational Method" among the methods used for surface runoff calculation in the literature.

The calculated flow rates are the peak discharge values that may occur every 10 years in each basin, and a transition from these values into the annual total surface runoff value has been carried out. The lake and dam reservoir volumes have been divided into the calculated annual surface runoff values, and the hydraulic retention time (Tw) value required for the Vollenweider method for each water body has been calculated.

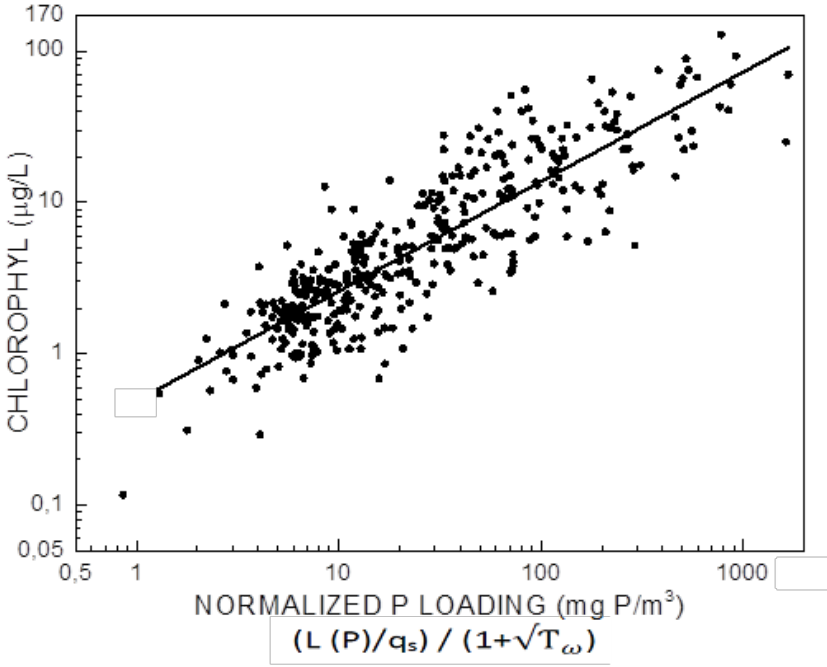

Figure 7. Association of Chlorophyll a parameter and TP load [5]

\subsection{Water quality monitoring studies}

Lake water samples were taken monthly (from April 2015 to April 2016) from 7 sampling points (Figure 8) and 3 different depths (surface, middle depth and deep depth) during 1-year period in the scope of HHAP Project [23]. Sampling locations and each depth of sampling for each sampling points were given in Table 4. These sampling locations and depths were chosen on site by monitoring team and previous studies considered too. Water samples were analyzed according to Standard Methods [24]. Alkalinity (mg/ $\mathrm{L} \mathrm{CaCO}_{3}$ ) [2320 B. Titration Method], Secchi Disc (m) Chlorophyll-a analysis [S.M 10200 H. Spectrophotometric method], Total Nitrogen and Total Phosphorus (mg/L) [4500- P A, 4500- P J.]. Only, $\mathrm{TN}, \mathrm{TP}$ and chlorophyll -a results were evaluated in order to calculate assimilation capacity with proposed approach.

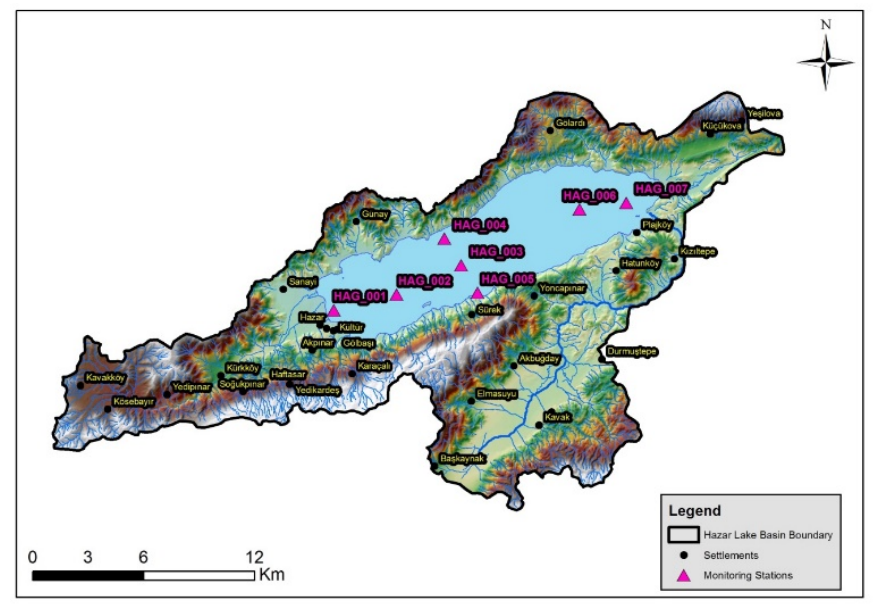

Figure 8. Monitoring stations [23]. 
Table 4. Water quality sampling stations' information

\begin{tabular}{|c|c|c|c|}
\hline Station & Latitude & Longitude & $\begin{array}{c}\text { Sampling } \\
\text { Depth }\end{array}$ \\
\hline & & & 1 \\
\hline \multirow{3}{*}{ HAG_1 } & $38^{\circ} 27^{\prime} 27.02^{\prime \prime} \mathrm{N}$ & 39¹8'29.75" E & 20 \\
\hline & & & 40 \\
\hline & & & 1 \\
\hline \multirow[t]{3}{*}{ HAG_2 } & $38^{\circ} 27^{\prime} 53.77^{\prime \prime} \mathrm{N}$ & $39^{\circ} 20^{\prime} 49.91^{\prime \prime} \mathrm{E}$ & 30 \\
\hline & & & 60 \\
\hline & & & 1 \\
\hline \multirow{3}{*}{ HAG_3 } & $38^{\circ} 28^{\prime} 44.55^{\prime \prime} \mathrm{N}$ & $39^{\circ} 23^{\prime} 14.10^{\prime \prime} \mathrm{E}$ & 40 \\
\hline & & & 80 \\
\hline & & & 1 \\
\hline \multirow[t]{3}{*}{ HAG_4 } & $38^{\circ} 29^{\prime} 31.64^{\prime \prime} \mathrm{N}$ & $39^{\circ} 22^{\prime} 37.46^{\prime \prime} \mathrm{E}$ & 15 \\
\hline & & & 30 \\
\hline & & & 1 \\
\hline \multirow[t]{3}{*}{ HAG_5 } & $38^{\circ} 27^{\prime} 56.43^{\prime \prime} \mathrm{N}$ & $39^{\circ} 23^{\prime} 50.52^{\prime \prime} \mathrm{E}$ & 20 \\
\hline & & & 40 \\
\hline & & & 1 \\
\hline \multirow[t]{3}{*}{ HAG_6 } & $38^{\circ} 30^{\prime} 21.87^{\prime \prime} \mathrm{N}$ & 39²7'39.71" E & 40 \\
\hline & & & 80 \\
\hline & & & 1 \\
\hline \multirow[t]{2}{*}{ HAG_7 } & $38^{\circ} 30^{\prime} 33.22^{\prime \prime} \mathrm{N}$ & $39^{\circ} 29^{\prime} 23.66^{\prime \prime} \mathrm{E}$ & 40 \\
\hline & & & 80 \\
\hline
\end{tabular}

\subsection{Determining the Hazar Lake total phosphorus assimilation capacity}

According to the approach given in section 2.3, calculations have been made and the normalized TP load corresponding to the value given for "chlorophyll- $a$ " parameter. For this purposes 3 different TP values were calculated with applying oligotrophic and mesotrophic limit values of chlorophyll- $a$ is specified in Table 9: Limit Values of the Trophic Classification System in Lakes, Ponds and Dam Reservoirs) of the Surface Water Quality Regulations, Appendix-6 in the lakes and dam reservoirs [25] and observed values of chlorophyll-a during monitoring studies. The L (P) phosphorus load corresponding to the determined normalized TP load has been calculated and accepted as the assimilation capacity.

\section{Results and discussion}

\subsection{Flow results}

Although obtained site observations flowrates values were used for assimilation capacity calculations, flow results were also calculated by rationale method in order to show absence of required and satisfied flowrate data. In order to apply rational method Hazar Lake Basin's land use was taken out CORINE 2018 data, average long path was calculated by GIS tool, "c" coefficients were taken from Table 1. Calculated weighted surface runoff coefficients were given in Table 5.
Table 5. Hazar Lake Basin's surface runoff coefficients and areas based on CORINE 2018 land use data

\begin{tabular}{|c|c|c|c|}
\hline Code 2018 & $\begin{array}{l}\text { Area } \\
\text { (ha) }\end{array}$ & $\begin{array}{l}\text { Surface } \\
\text { Runoff } \\
\text { Coeff., c }\end{array}$ & $\begin{array}{l}\text { Weighted } \\
\text { surface } \\
\text { runoff coeff. } \\
\left(\mathrm{C}_{\mathrm{i}} \mathrm{A}_{\mathrm{i}}, \mathrm{ha}\right) \\
\end{array}$ \\
\hline $\begin{array}{l}\text { Industrial or commercial } \\
\text { units (121) }\end{array}$ & 26,85 & 0,85 & 22,82 \\
\hline Pastures (231) & 143,48 & 0,35 & 50,22 \\
\hline $\begin{array}{l}\text { Land principally occupied } \\
\text { by agriculture, with } \\
\text { significant areas of natural } \\
\text { vegetation (243) }\end{array}$ & 3188,95 & 0,3 & 956,69 \\
\hline Coniferous forest (312) & 274,31 & 0,12 & 32,92 \\
\hline Natural grassland (321) & 13442,50 & 0,3 & 4032,75 \\
\hline $\begin{array}{l}\text { Transitional } \\
\text { woodland/shrub (324) }\end{array}$ & 1787,55 & 0,4 & 715,02 \\
\hline $\begin{array}{l}\text { Beaches, dunes, sands } \\
\text { (331) }\end{array}$ & 246,89 & 0,25 & 61,72 \\
\hline $\begin{array}{l}\text { Sparsely vegetated areas } \\
\text { (333) }\end{array}$ & 6125,99 & 0,4 & 2450,40 \\
\hline Water bodies (512) & 7892,57 & 0,001 & 7,89 \\
\hline $\begin{array}{l}\text { Discontinuous urban } \\
\text { (1121) }\end{array}$ & 151,96 & 0,55 & 83,58 \\
\hline Discontinuous rural (1122) & 66,26 & 0,45 & 29,82 \\
\hline $\begin{array}{l}\text { Non-irrigated arable land } \\
\text { (2111) }\end{array}$ & 141,05 & 0,45 & 63,47 \\
\hline $\begin{array}{l}\text { Permanently irrigated land } \\
\text { (2121) }\end{array}$ & 2249,96 & 0,35 & 787,48 \\
\hline $\begin{array}{l}\text { Complex cultivation } \\
\text { patterns (2421) }\end{array}$ & 330,41 & 0,4 & 132,16 \\
\hline $\begin{array}{l}\text { Irrigated complex } \\
\text { cultivation patterns (2422) }\end{array}$ & 2113,47 & 0,3 & 634,04 \\
\hline Bare rock (3321) & 161,17 & 0,9 & 145,05 \\
\hline Total & $38.343,38$ & & $10.206,04$ \\
\hline
\end{tabular}

GIS analyses of Hazar Lake's Basin show that longest runoff length in the basin is 24199 m (Behrimaz River) and its' 1.507924 slopes as percentage which means every 100 -meterlong distance makes 1.507924-meter elevation difference.

Flowrate were calculated by using rational method via Equation 1 after Equation 2-Equation 5 was calculated respectively and $\mathrm{C}_{\mathrm{w}}, \mathrm{K}$, Tc and corrected I values obtained. After required values inserted in Equation 1 calculated flowrate value is $5.9 \mathrm{~m}^{3} / \mathrm{s}$. General Directorate of Water Affairs (DSI) has long time flowrate data and annual average flowrate was $1.26 \mathrm{~m}^{3} / \mathrm{s}$ for between 1984 and 2011 years. Most recent study reported the maximum flow was $2.95 \mathrm{~m}^{3} / \mathrm{s}$ was in March and minimum flow was $0.35 \mathrm{~m}^{3} / \mathrm{s}$ in October with a mean flowrate $1.40 \mathrm{~m}^{3} / \mathrm{s}$ [20]. In this study DSİ data were used in order to determine hydraulic retention time and then normalized TP values. 


\subsection{Monitoring results}

As mentioned in section 2.4, water quality samples were taken at 3 different depth and 7 different sampling locations and during April 2015-April 2016 period monthly. Since the stratification is over 10 meters and it is a deep lake, surface sampling has been taken into consideration (Figure 9). Another reason was why surface data used that deep lake may not allow mixing and stratification apart from temperature profile. This approach was supported by recent conducted study in Hazar Lake that lake was dimictic with completely mixed in spring and autumn and stratified during summer session forming a thermocline below 10 meter $[18,21]$.

One of the best way the assessment of chlorophyll-a in order to apply proposed approach researchers mentioned that growing season and/or average summer epilimnetic algal chlorophyll need to be taken [14,26]. Therefore, instead of use all year data, 9 sampling periods between March to September including 2016 March and April months were taken consider for assessment of water quality.

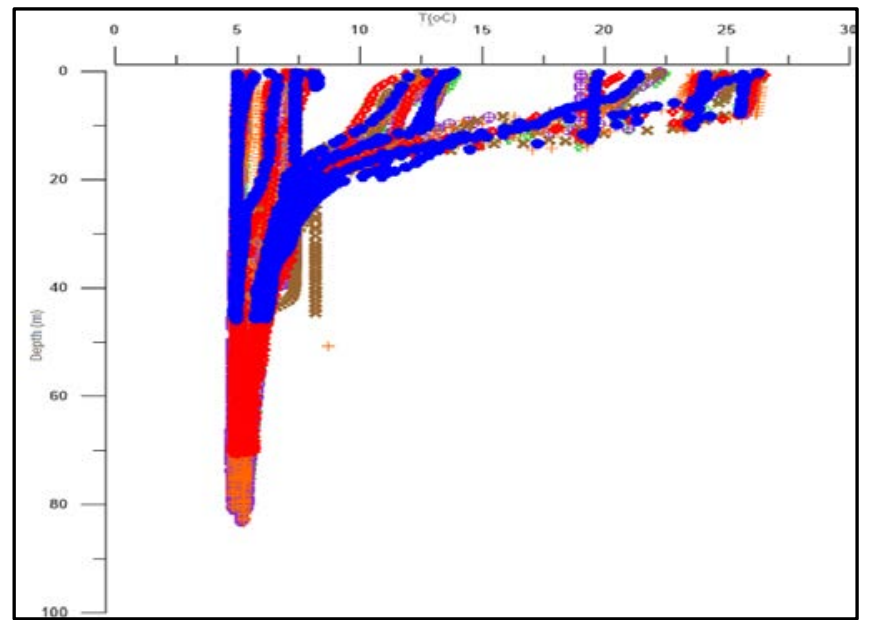

Figure 9. Temperature profile assessment

When the surface data were evaluated Hierarchical Cluster analysis was done with 63 data. Based on this cluster analysis of chlorophyll -a, TN, TP values of 7 sampling points could be used as one set. As a result of cluster analyses and temperature profile assessment was conducted with number of 63 surface data for each considered water quality parameters; alkalinity, chlorophyll-a, TN and TP.
Table 6. Statistical analysis of monitoring data

\begin{tabular}{|c|c|c|c|c|c|}
\hline & & $\begin{array}{l}\text { Alkalinity } \\
(\mathrm{mg} / \mathrm{L} \\
\left.\mathrm{CaCO}_{3}\right) \\
\end{array}$ & $\begin{array}{l}\text { Chlorophyll } \\
\text {-a }\left(\mathbf{m g} / \mathbf{m}^{3}\right)\end{array}$ & $\begin{array}{l}\text { TN } \\
(\mathrm{mg} / \mathrm{L})\end{array}$ & $\begin{array}{l}\text { TP } \\
(\mathbf{m g} / \mathrm{L})\end{array}$ \\
\hline \multirow[t]{2}{*}{$\mathrm{N}$} & Valid & 63.00 & 63.00 & 63.00 & 63.00 \\
\hline & Missing & 0.00 & 0.00 & 0.00 & 0.00 \\
\hline Mean & & 689.68 & 1.46 & 0.32 & 0.02 \\
\hline $\begin{array}{l}\text { Std. Error } \\
\text { of Mean }\end{array}$ & & 2.24 & 0.09 & 0.02 & 0.00 \\
\hline Median & & 690.00 & 1.30 & 0.27 & 0.02 \\
\hline $\begin{array}{l}\text { Std. } \\
\text { Deviation }\end{array}$ & & 17.78 & 0.72 & 0.12 & 0.01 \\
\hline Variance & & 316.03 & 0.52 & 0.01 & 0.00 \\
\hline Range & & 140.00 & 3.70 & 0.57 & 0.04 \\
\hline Minimum & & 580.00 & 0.10 & 0.14 & 0.00 \\
\hline Maximum & & 720.00 & 3.80 & 0.71 & 0.04 \\
\hline
\end{tabular}

Total numbers of 63 water samples were assessed in order to evaluate lake water quality in terms of alkalinity, Chlorophylla, TN and TP. Alkalinity results showed that the lake has moderately hard water. Total concentrations of alkalinity varied between 580 and $720 \mathrm{mg} \mathrm{CaCO}_{3} / \mathrm{L}$ during the study, similar results were reported by Feray et.al, 2011 [27]. Same similarities were seen for Chlorophyll concentrations with 0.1 to $3.80 \mathrm{mg} / \mathrm{m}^{3}$ varied and average is $1.46 \mathrm{mg} / \mathrm{m}^{3}$ in previous studies [11,18,21]. Koçer, et.al, 2012 were reported annual average concentration of Chlorophyll-a was found between 1.2-1.4 $\mu \mathrm{g} / \mathrm{L}$ with a $2.2 \mu \mathrm{g} / \mathrm{L}$ maximum concentration [21]. Koçer and Şen were reported 1.07-1.33 $\mu \mathrm{g} / \mathrm{L}$ Chlorophyll concentrations first 10 meter among the 53 samples [18].

These amounts of Chlorophyll-a concentration mean that low productivity of phytoplankton which was related alkali conditions of lake [8]. Trophic state of lake was found between oligotrophic and mesotrophic according to national legislation (YSKY, 2016, Appendix VI, Table 9) when considering to growing season concentrations data of TN, TP and Chlorophyll-a. Another important finding was TN:TP ratio of Hazar Lake. Proposed approach can be applied only when the lake limiting nutrient is phosphorus. In this study, phosphorus was found as limiting nutrient with $16 \mathrm{TN}$ :TP ratio for Hazar Lake.

\subsection{Calculated NP loads based on Vollenweider approach}

In this section 3 different TP values were calculated. First one is for current situation (observed chlorophyll -a results, 1.46 $\mu \mathrm{g} / \mathrm{L})$, second one is upper oligotrophic conditions $(<3,5 \mu \mathrm{g} / \mathrm{L}$ Chl-a) and last one is for upper mesotrophic conditions $(<9$ $\mu \mathrm{g} / \mathrm{L}$ Chl-a). 
Table 7. NP values for each corresponding chlorophyll-a values based on Vollenweider approach

\begin{tabular}{cc}
\hline Chlorophyll -a $(\boldsymbol{\mu g} / \mathbf{L})$ & $\mathbf{N P}\left(\mathbf{m g} / \mathbf{m}^{3}\right)$ \\
\hline 1.46 & 4 \\
3.5 & 9 \\
9 & 55 \\
\hline
\end{tabular}

In order to applying Vollenweider approach Hazar Lake required specifications were given below in Table 8. Lake Volume and surface area obtained from DSI that in charge of operations of the lake. Hazar Lake average depth is determined to be $98 \mathrm{~m}$ [28].

Table 8. Hazar Lake's required data for applying Vollenweider approach

\begin{tabular}{|c|c|c|c|c|c|c|}
\hline $\begin{array}{l}\text { Lake } \\
\text { Vol. } \\
\left(\mathrm{hm}^{3}\right)\end{array}$ & $\begin{array}{l}\text { Lake Volume } \\
\left(\mathrm{m}^{3}\right)\end{array}$ & $\begin{array}{l}\text { Lake } \\
\text { Surface } \\
\text { Area } \\
\left(\mathbf{m}^{2}\right)\end{array}$ & $\begin{array}{l}\text { Aver. } \\
\text { Dept } \\
\text { h (m) }\end{array}$ & $\begin{array}{l}\text { Flow } \\
\text { rate } \\
\left(\mathrm{m}^{3} / \mathrm{s}\right) \\
*\end{array}$ & $\begin{array}{l}\text { Flow } \\
\text { rate } \\
\left(\mathrm{m}^{3} / \mathbf{y}\right)\end{array}$ & $\mathbf{T}_{\mathrm{w}}(\mathbf{y})$ \\
\hline 7.000 & 7.000 .000 .000 & 78.970 .000 & 98 & 1,26 & 39.735 .360 & 176,17 \\
\hline
\end{tabular}

*Long term annual average flowrate.

Average chlorophyll-a is $1.46 \mathrm{mg} / \mathrm{L}$ and NP is 4 based on Vollenweider graph. When the Eq 6 was applied Lp was 2.27 ton $\mathrm{P} / \mathrm{y}$. This amount is referred current TP situation. After LP was obtained assimilation capacity of Hazar Lake might be calculated easily in order to meet desired trophic state.

\subsection{Calculated phosphorus assimilation capacity of Hazar Lake}

Required information were calculated previous sections applying Equations 1-6 in order to calculate assimilation capacity of Hazar Lake in line with Vollenweider OECD approach. In this study, 3 different scenarios were assumed, conserving current trophic state, allowing the increasing of TP load up to oligotrophic boundary condition and mesotrophic boundary condition. Calculated annual ton TP capacities are 2.51, 9.41 and 34.5 for current, oligotrophic and mesotrophic situation respectively. These findings point that the lake TP assimilation capacity might be increased 3.7 times in order to sustain oligotrophic situation or having 13.7 times higher capacity for mesotrophic situation. Obtained results were given in Table 9.

Table 9. NP values for each corresponding chlorophyll-a values based on Vollenweider approach

\begin{tabular}{|c|c|c|c|c|}
\hline & 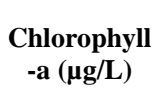 & $\underset{\left(\mathbf{m g} / \mathbf{m}^{2} / \mathbf{y}\right)}{\mathbf{L p}}$ & $\underset{\text { (ton/y) }}{\mathbf{T P}}$ & $\begin{array}{c}\text { Assimilation } \\
\text { Capacitive } \\
\text { (ton P/y)* }\end{array}$ \\
\hline $\begin{array}{c}\text { Current } \\
\text { Situation }\end{array}$ & 1.46 & 31.8 & 2.51 & - \\
\hline $\begin{array}{l}\text { Oligotrophic } \\
\text { Situation }\end{array}$ & $3.5^{* *}$ & 119 & 9.41 & 6.90 \\
\hline $\begin{array}{l}\text { Mesotrophic } \\
\text { Situation }\end{array}$ & $9.0^{* *}$ & 437 & 34.50 & 32.00 \\
\hline
\end{tabular}

\section{Conclusions}

The aim of this study is to calculate the phosphorus assimilation capacity in phosphorus limiting lakes and dams semi-empirically using the available data and Vollenweider approach without model software. Therefore, Hazar Lake were chosen as a case study in order to plenty of available water quality data especially chlorophyll -a, TN and TP. As a result of applying Vollenweider approach that Hazar Lake's TP capacity has been already not filled and might have annually 6.90 ton TP to sustain oligotrophic condition or annually 32.00 ton TP for being mesotrophic lake. Current literature and in this study shows Hazar Lake is in good water quality and able to handle almost 13.7 times more TP loading a year. However, we suggest the Lake current water quality should sustain and new studies should be done next decades. In fact, that due to protection statute of Lake and having good potential being RAMSAR site the lake needs to be protected. Water Framework Directive required areas designated for the protection of habitats or species where the maintenance or improvement of the status of water is an important factor in their protection, including relevant Natura 2000 sites.

\section{Acknowledgements}

This study was prepared within the scope of the project "Determination of Sensitive Areas and Water Quality Objectives for Turkish River Basin Districts” (2012-2015) conducted by the former Ministry of Forestry and Water Affairs/Directorate General for Water Management in collaboration with TUBITAK MRC Environment and Cleaner Production Institute. The authors thank the General Directorate of Water Management for financial support. The lake monitoring studies were carried out by Firat University (Prof. Dr. Bülent Şen, Prof. Dr. Feray Sönmez and their team). The authors also thank TUBITAK MRC Environment and Cleaner Production Institute's laboratory staff and GIS team for their valuable support.

\section{References}

[1]. Vollenweider R.A., "Advances in defining critical loading levels for phosphorus in lake eutrophication”, Mem. 1st ital. Idrobiol., 33, (1976), 53-58.

[2]. Håkanson L., Bryhn A.C., Hytteborn J.K., “On the issue of limiting nutrient and predictions of cyanobacteria in aquatic systems”, Sci. Total Environ., 379, (2007), 89-108.

[3]. Ekholm P., "N: P ratios in estimating nutrient limitation in aquatic systems”, Finnish Environ. Inst., (2008), 1114. 
[4]. Sterner R.W., "On the phosphorus limitation paradigm for lakes”, Int. Rev. Hydrobiol., 93, (2008), 433-445.

[5]. Jones R.A. Lee G.F., "Use of Vollenweider-OECD modeling to evaluate aquatic ecosystem functioning”, Funct. Test. Aquat. Biota Estim. Hazards Chem., ASTM STP 988, J. Caims, Jr., and J.R. Pratt, Eds., American Society for Testing Materials, Philadephia, (1988), 17-27.

[6]. Ryding S.-O., Forsberg C., "Short-term load-response relationships in shallow, polluted lakes”, In Hypertrophic Ecosyst., Springer, (1980), 95-103.

[7]. Jones J.R., Bachmann R.W., "Prediction of phosphorus and chlorophyll levels in lakes”, J. (Water Pollut. Control Fed., (1976), 2176-2182.

[8]. Schindler D.W., "Factors regulating phytoplankton production and standing crop in the world's freshwaters”, Limnol. Oceanogr. 23, (1978), 478-486.

[9]. Chapra S.C., "Total phosphorus model for the Great Lakes”, J. Environ. Eng. Div., 103, (1977), 147-161.

[10]. Canfield Jr D.E., Bachmann R.W., "Prediction of total phosphorus concentrations, chlorophyll a, and Secchi depths in natural and artificial lakes”, Can. J. Fish. Aquat. Sci., 38, (1981), 414-423.

[11]. Sonmez F., Kocer M.A.T., Alp M.T., Sen B., “An Evaluation On Characterıstıc Diatoms Of Alkaline Lake Hazar (Turkey)”, Feb-Fresenıus Environ. Bull., (2018), 8519.

[12]. Håkanson L., Jansson M., "Principles of lake sedimentology”, vol. 109, Springer-verlag, Berlin, (1983), pp. 24-31.

[13]. Emmanuel E., Keck G., Blanchard J.-M., Vermande P., Perrodin Y., "Toxicological effects of disinfections using sodium hypochlorite on aquatic organisms and its contribution to AOX formation in hospital wastewater”, Environment international, 30, (2004), 891-900.

[14]. Nürnberg G.K., “Trophic state of clear and colored, soft-and hardwater lakes with special consideration of nutrients, anoxia, phytoplankton and fish”, Lake Reserv. Manag., 12, (1996), 432-447.

[15]. Vollenweider R. A., "Eutrophication of waters: monitoring, assessment and control”. Organisation for Economic Co-operation and Development; Washington, DC: Sold by OECD Publications and Information Center, 1982.
[16]. Whittaker R.H., "Communities and ecosystems”, Communities Ecosyst., Macmillan Publishing Co., Inc., New York, USA, 1975.

[17]. Vollenweider R.A., Kerekes J., “OECD cooperative programme for monitoring of inland waters (eutrophication control)”, Synth. Report. OECD, Paris, 1980.

[18]. Kocer M.A.T., Şen B., "Some factors affecting the abundance of phytoplankton in an unproductive alkaline lake (Lake Hazar, Turkey)”, Turk. J. Botany., 38, (2014), 790-799.

[19]. Ayaz S., "Hazar Lake Management Plan Project I. Stage”, TÜBİTAK MRC, Energy Systems and Environment Institute, 2002.

[20]. Varol M., “Stream Inputs To Lake Hazar (Eastern Anatolia-Turkey)”, Environ. Eng.Manag. J., 18, 1, (2019), 185-194.

[21]. Kocer M.A.T., Şen B., “The seasonal succession of diatoms in phytoplankton of a soda lake (Lake Hazar, Turkey)”, Turk. J. Botany., 36, (2012), 738-746.

[22]. TURKSTAT, “Turkish Statistical Institute 2020 Reports”, Available: https://www.tuik.gov.tr/ [Accessed:April 13, 2021]

[23]. TÜBİTAK MRC, "HHAP Project Determination of Sensitive Areas and Water Quality Objectives for Turkish River Basin Districts Project (2012-2015)”, TÜBİTAK MRC, Environment and Cleaner Production Institute, 2016

[24]. Baird R.B., "Standard Methods for the Examination of Water and Wastewater", 23 ${ }^{\text {rd }}$ ed., Water Environment Federation, American Public Health Association, American Water Works Association, 2017.

[25]. YSKY, “Regulation on Surface Water Quality (RSWQ) (Turkey) (2016) 29797/ 16.8.2016”, Ministry of Forestry and Water Affairs, Available: https://www.resmigazete.gov.tr/eskiler/2016/08/201608 10-9.htm. [Accessed: April 13, 2021]

[26]. Phillips G., Pietiläinen O.-P., Carvalho L., Solimini A., Solheim A.L., Cardoso A.C., "Chlorophyll-nutrient relationships of different lake types using a large European dataset”, Aquat. Ecol., 42, (2008), 213-226.

[27]. Sonmez, F., Sen, B., "Seasonality and Distribution of Epilithic Diatoms in an Alkaline Lake (Lake Hazar, 
Elazig, Turkey)”, Fresenius Environmental Bulletin, 20, (6), 1458-1464.
[28]. Şen B., Alp M.T., Özrenk F., Ercan Y., Yıldırım V., “A study on the amount of plant nutrients and organic matters carried into the Hazar Lake (Elazığ-Türkiye)", Fresenius Environ. Bull., 8, (1999), 272-279. 